\title{
AKUNTABILITAS PENGELOLAAN DANA BERGULIR PADA UPK-G
}

\author{
Syarifah Alawiyyah ${ }^{1}$ \\ Akuntansi FEB \\ Universitas Brawijaya Malang \\ alawiyyayd@gmail.com
}

\author{
Unti Ludigdo² \\ Akuntansi FEB \\ Universitas Brawijaya Malang \\ untiludigdo@ub.ac.id
}

\author{
Aji Dedi Mulawarman ${ }^{3}$ \\ Akuntansi FEB \\ Universitas Brawijaya Malang \\ ajidedim@gmail.com
}

\begin{abstract}
ABSTRAK
Penelitian ini bertujuan untuk mendeskripsikan akuntabilitas pengelolaan dana bergulir dalam aspek pelaporan pada Program Gerbangmastaskin. Penelitian ini dilakukan melalui pendekatan kualitatif dengan menggunakan paradigma interpretif. Tanggung jawab pengurus UPK memberikan pelaporan terhadap pengelolaan dana bergulir ditunjukkan dalam bentuk laporan penggunaan dana dan laporan keuangan UPK. Hasilnya menunjukkan bahwa UPK selalu menyiapkan laporan penggunaan dananya karena suatu keharusan sedangkan laporan keuangan hanya dibuat sebatas kebutuhan primer UPK dan hanya diberikan kepada pendamping. Laporan keuangan tidak diberikan kepada Sektap Kota sebagai pelaksana program kegiatan sehingga perkembangan dana UPK dari tahun ke tahun secara rinci tidak dapat diketahui oleh Sektap Kota. Sejauh ini program Gerbangmastaskin telah berperan memberdayakan perekonomian masyarakat melalui perguliran dana simpan pinjam untuk usaha masyarakat.
\end{abstract}

Kata Kunci : $\quad$ Akuntabilitas; Pelaporan; Gerbangmastaskin; Unit pengelola keuangan

\begin{abstract}
This study aims to describe accountability of Gerbangmastaskin Fund management in reporting aspect. This research is done through qualitative approach. The responsibilities of Financial Management Unit (FMU) (UPK, Indonesian: Unit Pengelola Keuangan) management to report to the management of Gerbangmastaskin Fund are shown in the form of reports on the use of funds and financial statements of FMU. The results show that FMU always prepares reports of the use of funds due to a obligation requirement, in order to financial statements that are only made limited to the primary needs of the UPK and only provided to the companion. The financial statements are not given to Sektap as the executor of the activity program so that FMU fund development from year to year in detail can not be known by Sektap. So far the Gerbangmastaskin program has been instrumental in empowering the community's economy through revolving savings and loans for community businesses.
\end{abstract}

Keywords: Accountability; Reporting; Gerbangmastaskin Financial management unit.

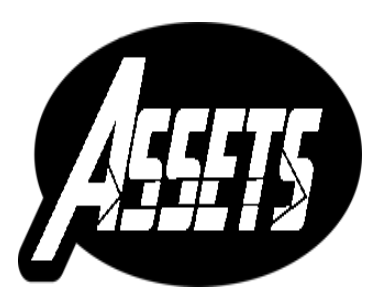

ASSETS

Jurnal Akuntansi dan Pendidikan

Vol. 6 No. 2

Hlmn. 130-141

Madiun, Oktober 2017 p-ISSN: 2302-6251 e-ISSN: 2477-4995

Artikel masuk: 16 Agustus 2017

Tanggal diterima: 25 Oktober 2017 


\section{PENDAHULUAN}

Program pengentasan kemiskinan terkonseptualisasi dan diimplementasikan di berbagai negara di seluruh dunia melalui serangkaian program yang ditargetkan mampu meningkatkan kesejahteraan masyarakat maupun tidak (Oyesanmi, Eboiyehi, dan Adereti, 2005). Aspek yang memengaruhi untuk mendukung tujuan kesejahteraan masyarakat, mengentaskan kemiskinan, serta memberdayakan masyarakat, yaitu sosial dan lingkungan. Pemerintah bertanggung jawab mengarahkan bantuan sosialnya untuk mencakup aspek tersebut. Selaras dengan hal tersebut maka Pemerintah Provinsi Kalimantan Selatan turut mengupayakan dengan pelaksanaan program kegiatan Gerakan Pembangunan Masyarakat dan Pengentasan Kemiskinan (Gerbangmastaskin). BPS Provinsi Kalimantan Selatan (2016) dalam menunjukkan perkembangan tingkat kemiskinan di Kalimantan Selatan menjelaskan bahwa Program Gerbangmastaskin merupakan program andalan Pemerintah Provinsi Kalimantan Selatan untuk pengentasan kemiskinan, selain program Pemerintah Pusat yang disalurkan ke seluruh Provinsi di Indonesia seperti Bantuan Langsung Tunai (BLT) dan Program Keluarga Harapan (PKH).

Program Gerbangmastaskin berjalan sejak tahun 2007 dan program ini ditargetkan oleh Gubernur Provinsi Kalimantan Selatan dapat menurunkan jumlah masyarakat miskin di wilayah Kalimantan Selatan yang sebelumnya 4,76\% pada tahun 2014 menjadi 3,95\% pada tahun 2015 (Anonim, 2014). Program Gerbangmastaskin didasarkan pada pendekatan Tridaya (pemberdayaan manusia, pemberdayaan usaha, dan pemberdayaan lingkungan). Berdasarkan hal tersebut maka sasaran penyaluran Dana Gerbangmastaskin adalah Rumah Tangga Miskin (RTM) yang dikategorikan dalam Rumah Tangga Miskin Berpotensi (RTMB) dan Rumah Tangga Miskin Rentan (RTMR). Dana Gerbangmastaskin didanai murni dari dana APBD sehingga menunjukkan efektivitas dan kemandirian pemerintah daerah dalam mendukung program pengentasan kemiskinan. Pengelolaan Dana Gerbangmastaskin dilakukan oleh Unit Pengelola Keuangan (UPK) yang dipilih melalui musyawarah kelurahan dan ditetapkan oleh Lurah. UPK menghasilkan laporan penggunaan dana sebagai bentuk pertanggung jawaban UPK, akuntabilitas kepada pemerintah atas dana yang digunakan dan disalurkan untuk masyarakat kemudian dibutuhkan laporan keuangan sebagai sumber informasi yang digunakan untuk menunjukkan arus dana bergulir UPK dari tahun ke tahun.

Dana yang digunakan untuk peningkatan ekonomi masyarakat dalam bentuk simpan pinjam dana, terus bergulir dan cenderung berkembang melalui tambahan modal yang disalurkan lagi oleh pemerintah maupun dari hasil jasa pinjaman. Wira dan Gustati (2014) menunjukkan optimalisasi pelaksanaan dana bergulir, dan berdasarkan aktivitas usaha yang dilakukan melalui pinjaman modal dari dana bergulir dinilai optimal dan mampu meningkatkan perekonomian masyarakat dengan meningkatnya kemajuan usaha, omzet usaha serta keuntungan usaha. Pertanggung jawaban pengelolaan dana bergulir seperti pada program PNPM Mandiri sebagai salah satu program pengentasan kemiskinan ditunjukkan oleh Yuliati (2015) melalui laporan keuangan BKM yang dipersiapkan oleh UPK.

Akuntabilitas merupakan tanggung jawab yang harus dipenuhi terutama pada dana yang ditujukan untuk memberdayakan masyarakat dan mengentaskan kemiskinan. Kilby (2006) menunjukkan adanya dilema akuntabilitas pada program pemberdayaan yang dihadapi LSM, dan rendahnya pengaruh akuntabilitas dalam proses pemberdayaan bagi masyarakat miskin dan terpinggirkan di negara-negara berkembang. LSM menganggap bahwa pergeseran akuntabilitas terhadap konstituen (penerima manfaat) dapat melemahkan pengendalian programnya, menciptakan 
ketegangan, dan mengalihkan peran LSM dari konstituennya untuk kepentingan publik (Kilby, 2006). Akuntabilitas sebagai bentuk pertanggung jawaban yang diberikan oleh UPK atas penggunaan dana sebagaimana Sucipto (2012) yang menunjukkan bentuk akuntabilitas UPK melalui pembukuan dana UPK.

Terwujudnya tujuan pemerintahan yang baik pun didukung melalui akuntabilitas penanggung jawab pelaksana kegiatan. Kemitraan sinergis antara negara dan masyarakat (civil society) dikedepankan dalam sistem demokrasi dengan pengelolaan yang efisien dan jauh dari korupsi (Nugroho, 2014:178). Mekanisme akuntabilitas pada pengelolaan dana program pengentasan kemiskinan perlu untuk dikelola dan diawasi dengan benar untuk menghindari permasalahan dan mencegah terjadinya penyimpangan. Pemerintah, masyarakat maupun LSM sekali pun yang terlibat pada program pengentasan kemiskinan berperan dalam mewujudkan praktik pengelolaan keuangan yang sehat. Transparansi dan akuntabilitas pengelolaan dana bergulir perlu ditingkatkan, untuk itu pengelolaannya harus dilakukan sesuai dengan praktik bisnis yang sehat (KSAP, 2008).

Pelaporan dan pertanggung jawaban sebagai bentuk akuntabilitas pada pengelolaan dana sosial kemasyarakatan diatur oleh pemerintah melalui Permendagri 32/2011. Penerima bantuan dana menyampaikan laporan penggunaan dana, pertanggung jawaban pemerintah daerah yang meliputi antara lain usulan calon penerima manfaat, keputusan kepala daerah atas penetapan penerima manfaat, naskah perjanjian hibah daerah, pakta integritas berupa pernyataan penggunaan dana yang sesuai dari penerima hibah, serta bukti transfer uang ataupun serah terima barang/jasa.

Permendagri 32/2011 juga menunjukkan bahwa pertanggung jawaban penerima manfaat dilakukan baik secara formal maupun material atas penggunaan dana yang meliputi laporan penggunaan dana, pernyataan penggunaan dana yang sesuai dengan naskah perjanjian hibah daerah, beberapa bukti pengeluaran maupun bukti serah terima barang yang lengkap dan sah sesuai dengan perundang-undangan yang dapat disimpan dan digunakan sebagaimana mestinya oleh penerima manfaat sebagai obyek pemeriksaan di kemudian hari. Mekanisme tersebut menunjukkan bahwasanya pemerintah tidak mengabaikan sistem dan prosedur serta memberikan mekanisme pertanggung jawaban yang secara lengkap dipenuhi dan dipatuhi baik oleh aparat pelaksana kegiatan maupun bagi penerima manfaat.

Akuntabilitas merupakan bagian dari praktik akuntansi yang berperan dalam perubahan suatu organisasi, sebagaimana Hopwood (1990:16) yang menjelaskan bahwa akuntansi dapat membangun bentuk dan batasan terhadap suatu organisasi, bagaimana, dan seperti apa akuntansi terjadi. Mardiasmo (2009:20) mengungkapkan bahwa akuntabilitas publik merupakan tanggung jawab atau kewajiban pihak pemegang amanah (agent) kepada pihak pemberi amanah (principal) dalam mempertanggungjawabkan, menyajikan, memberikan pelaporan serta mengungkapkan segala aktivitas dan kegiatan. Berdasarkan hal tersebut peneliti ingin menunjukkan bagaimana realitas yang terjadi pada pelaporan UPK sebagai bentuk akuntabilitas pengelolaan dana bergulir pada program Gerbangmastaskin.

\section{METODE PENELITIAN}

Penelitian ini dilakukan dengan pendekatan kualitatif melalui paradigma interpretif. Sebagaimana penelitian kualitatif yang situasional, lingkup penelitian dalam situasi sosial bahkan pada kompleksitas yang terjadi di masyarakat. Situasi sosial meliputi orang-orang (actor), aktivitas (activity) pada lokasi/tempat (place) tertentu (Sugiyono, 2015). Kompleksitas yang terjadi di masyarakat tentunya 
menunjukkan suatu permasalahan yang terjadi pada individu masyarakat itu sendiri maupun kelompok masyarakat. Penelitian ini dilakukan pada salah satu Unit Pengelola Keuangan (UPK) di Kota Banjarbaru yang menangani Dana Gerbangmastaskin yaitu UPK Gandaria. UPK mengelola dan menyalurkan dana dari pemerintah langsung kepada masyarakat sehingga UPK berinteraksi secara langsung kepada masyarakat.

Pada penyaluran dana gerbangmastaskin, pengurus UPK dalam pelaksanaannya tidak terlepas dari mekanisme yang telah ditetapkan, baik oleh pemerintah selaku pelaksana kegiatan maupun tim pendamping program kegiatan. Agar permasalahan yang terkait dengan aspek sosial organisasi dapat diungkap dan ditelaah lebih dalam, perlu dilakukan penelitian dengan pendekatan studi kasus. Terdapat beberapa hal yang ingin dikonfirmasi dan diperjelas oleh peneliti. Keakuratan informasi akan didapatkan melalui informan-informan yang tepat dan berkaitan langsung dengan situs penelitian. Untuk itu, peneliti terlebih dahulu harus mengetahui informaninforman utama yang berkaitan dengan permasalahan yang diteliti.

Peneliti sebagai instrumen kunci dalam penelitian kualitatif (Sugiyono, 2015: 60). Peneliti sebagai instrumen utama memiliki keterlibatan dalam proses penelitian kualitatif agar dapat memahami permasalahan sosial yang ada dilapangan. Penelitian ini dilakukan di salah satu Unit Pengelola Keuangan Gerbangmastaskin yang ada di Kota Banjarbaru yaitu UPK Gandaria. Informan yang dipilih dalam penelitian ini diantaranya 1) MT, Pengurus UPK yang secara aktif menangani pengelolaan dana bergulir di masyarakat; 2) GN, Pendamping; 3) DN, staf keuangan; 4) CR, sektap kota.

Teknik pengumpulan data dilakukan dengan wawancara dengan informaninforman utama, observasi dan dokumentasi pada dokumen-dokumen terkait pertanggung jawaban pelaksanaan kegiatan dan proses pengelolaan dana bergulir. Sugiyono (2015: 5-6) mengungkapkan bahwa peneliti berperan sebagai human instrument dalam melakukan penelitian secara kualitatif dan berinteraksi dengan lebih dekat dengan sumber data sehingga dibutuhkan participant observation (observasi berperan serta) dan in depth interview (wawancara mendalam). Beberapa sumbersumber data yang didapat perlu di seleksi agar informasi yang didapat diyakini kebenarannya. Sugiyono (2015: 91) menunjukkan aktivitas dalam proses analisis data sebagaimana ditunjukkan oleh Miles and Huberman yang meliputi proses reduksi data (data reduction), display data (data display), dan simpulan (conclusion drawing/ verification). Vrederbregt (1987) dalam Mantra (2008: 114) mengungkapkan bahwa terdapat kemungkinan adanya "bias" dari data-data yang dikumpulkan namun jika bukan karena proses tersebut kita tidak akan mendapatkan data sama sekali. Mengurangi bias dalam mendapatkan data dapat dilakukan pada saat berinteraksi langsung dengan informan dengan meyakinkan kembali informasi yang telah disampaikan melalui suatu pernyataan ataupun pertanyaan berulang.

Berdasarkan sumber bukti yang dikumpulkan dan informasi yang diperoleh peneliti melalui serangkaian proses pengumpulan data mengarahkan peneliti untuk melihat keabsahan data, memilah dengan cermat melalui proses reduksi data agar dapat menempatkan beberapa informasi pada proporsinya masing-masing dan menemukan gambaran pada suatu hal baru (temuan) yang dapat dijadikan perhatian untuk hasil kajian selanjutnya berdasarkan realitas yang ditemukan pada pengelolaan dana bergulir. Data yang sudah dipilah dan diperiksa dibuat dalam bentuk manuskrip dan simpulan-simpulan penemuan penelitian, memverifikasi, dan mengonfirmasi hasil temuan. 


\section{HASIL PENELITIAN DAN PEMBAHASAN}

Badan Pemberdayaan Masyarakat dan Pemerintahan Desa Provinsi Kalimantan Selatan (2013) menjelaskan pengelolaan usaha dan keuangan UPK, sebagai berikut:

a. Dana Gerbangmastaskin yang digunakan sebagai modal UPK

Dana gerbangmastaskin digunakan seoptimal mungkin untuk pengembangan usaha masyarakat, dan dana tersebut dikembangkan sebagai modal pribadi. Pemilihan aktivitas usaha dilakukan dengan keberpihakan pada Rumah Tangga Miskin (RTM), klasifikasi jenis usaha yang menguntungkan, dan jenis usaha yang permanen dan berkelanjutan. Pengalokasian dana yang telah diatur sebesar minimal $80 \%$ untuk usaha simpan pinjam, kemudian $20 \%$ dari dana pemberdayaan usaha dapat digunakan sebagai usaha sektor riil UPK.

b. Pengelolaan usaha simpan pinjam

Pengelolaan usaha simpan pinjam memperhatikan prinsip pengelolaan usaha simpan pinjam dan permohonan pinjaman. Analisis kelayakan usaha dan peminjam memperhatikan aspek kelayakan perorangan, kelayakan anggota sebagai peminjam maupun kelayakan kelompok pada pokmas UEP yang telah berjalan. Realisasi dana pinjaman yang dipenuhi UPK kepada pokmas sesuai dengan kesepakatan kedua belah pihak. Pengelolaan dana simpan pinjam pada pokmas dilakukan dengan sistem tanggung renteng. Penanganan tunggakan dan kemacetan pinjaman dilakukan melalui prosedur-prosedur yang telah ditetapkan.

c. Pengembangan UPK sebagai lembaga usaha

Pengembangan UPK sebagai lembaga usaha dilakukan melalui pengembangan usaha UPK itu sendiri, pengembangan kemampuan SDM, pengembangan organisasi dan manajemen usaha, UPK sebagai Badan Usaha Milik Desa (BUMDes). Menyikapi UPK yang dipersiapkan untuk BUMDes, maka Kota Banjarbaru yang berdiri di pemerintahan kota membentuk koperasi primer gerbangmastaskin.

d. Pembukuan keuangan UPK

Pada dasarnya informasi keuangan dan pertanggung jawaban UPK dibutuhkan oleh semua pihak, dan tata administrasi akuntansi yang baik. Pembukuan dan pelaporan keuangan UPK dilakukan dengan pembukuan keuangan kegiatan pemberdayaan manusia maupun pemberdayaan lingkungan. Hal tersebut dilakukan sebagai pertanggung jawaban UPK atas aktivitas yang dilaksanakannya, kemudian diposkan pada akunnya masing-masing dan dicatat berdasarkan kode buku pembukuan UPK. Beberapa buku administrasi keuangan UPK antara lain mutasi kas harian, rekapitulasi kas harian, buku kas masuk, buku kas keluar, jurnal transaksi non kas, neraca saldo, dan laporan keuangan dan statistik.

e. Prosedur penanganan transaksi UPK

Terkait dengan pinjaman pokmas maka proses yang dilakukan yaitu menyiapkan permohonan pinjaman kepada UPK, pinjaman akan direalisasikan jika disetujui oleh UPK atas kelayakan penerima pinjaman, selanjutnya bendahara UPK menyiapkan bukti kas masuk penerimaan angsuran, dan sekretaris menyampaikan tunggakan dan pinjaman pokmas yang macet. Prosedur lainnya, yaitu mengatur uang setoran simpanan, surat menyurat, kas UPK serta pertanggung jawaban pembukuan keuangan yang dilakukan oleh bendahara, sekretaris, dan ketua.

Dana Gerbangmastaskin yang merupakan program Pemerintah Provinsi Kalimantan Selatan disalurkan dalam bentuk sharing dan mandiri. Dana sharing berasal dari APBD Provinsi Kalimantan Selatan (APBD 1) dan dana dampingan dari Pemerintah Kota (APBD 2) untuk UPK di 4 kelurahan. Secara rutin, Pemerintah Kota juga memberikan tambahan dalam bentuk dana mandiri untuk UPK di 6 Kelurahan. Alokasi Dana Gerbangmastaskin Kota Banjarbaru dapat dilihat pada Tabel 1 berikut: 
Tabel 1. Alokasi Dana Gerbangmastaskin

\begin{tabular}{cccc}
\hline \multirow{2}{*}{ Tahun } & \multicolumn{2}{c}{ Dana Sharing } & \multirow{2}{*}{ Mandiri (APBD 2) } \\
\cline { 2 - 3 } & Provinsi (APBD 1) & Kota (APBD 2) & \\
\hline 2015 & $\operatorname{Rp} 46.000 .000,00$ & $\operatorname{Rp~43.700.000,00~}$ & $\operatorname{Rp} 60.000 .000,00$ \\
2014 & $\operatorname{Rp} 50.000 .000,00$ & $\operatorname{Rp} 45.000 .000,00$ & $\operatorname{Rp} 60.000 .000,00$ \\
2013 & $\operatorname{Rp} 50.000 .000,00$ & $\operatorname{Rp} 45.000 .000,00$ & $\operatorname{Rp} 60.000 .000,00$ \\
2012 & $\operatorname{Rp} 50.000 .000,00$ & $\operatorname{Rp} 45.000 .000,00$ & $\operatorname{Rp} 60.000 .000,00$ \\
2011 & $R p 50.000 .000,00$ & $R p 45.000 .000,00$ & $\operatorname{Rp} 60.000 .000,00$ \\
\hline
\end{tabular}

Sumber: Surat Keputusan Walikota tentang Alokasi Dana Gerbangmastaskin Tahun 2011-2015.

Pemerintah Kota Banjarbaru satu-satunya daerah yang memberikan dana dampingan diatas ketentuan yang telah ditetapkan pemerintah provinsi Kalimantan Selatan, bahkan dana dampingan yang diberikan oleh pemerintah Kota Banjarbaru sampai dengan 90\%. Hal tersebut menjadi keunggulan dari Pengurus UPK Gerbangmastaskin di Kota Banjarbaru. Bahkan, setelah berakhirnya program Gerbangmastaskin pada tahun 2015, dana Gerbangmastaskin yang digulirkan untuk usaha simpan pinjam masih dapat terus dikelola oleh UPK hingga tahun 2016, dan masih akan dikelola lagi di tahun yang akan datang. Alokasi dana yang disalurkan untuk dana bergulir yang digunakan sebagai simpan pinjam untuk usaha ekonomi masyarakat memiliki proporsi yang lebih besar dibandingkan untuk pemberdayaan manusia maupun lingkungan. Alokasi dana bergulir dapat dilihat pada tabel 2 berikut ini:

Tabel 2. Alokasi Dana Bergulir Gerbangmastaskin

\begin{tabular}{ccr}
\hline Tahun & Sharing (APBD 1) & Mandiri (APBD 2) \\
\hline 2015 & $\operatorname{Rp~33.856.000,00}$ & $\operatorname{Rp~30.500.000,00~}$ \\
2014 & $\operatorname{Rp~32.800.000,00}$ & $\operatorname{Rp} 30.500 .000,00$ \\
2013 & $\operatorname{Rp~36.000.000,00}$ & $\operatorname{Rp} 30.500 .000,00$ \\
2012 & $\operatorname{Rp~36.000.000,00}$ & $\operatorname{Rp} 30.500 .000,00$ \\
2011 & $\operatorname{Rp~31.500.000,00}$ & $\operatorname{Rp} 33.000 .000,00$ \\
\hline
\end{tabular}

Sumber: Lembar Kerja UPK-G Penerima Dana Gerbangmastaskin Tahun 2011-2015.

Dana yang digulirkan untuk usaha simpan pinjam setiap tahunnya mengalami peningkatan dan penurunan seiring dengan bergulirnya dana tersebut di masyarakat. Peningkatan dapat terjadi melalui penambahan modal dari alokasi dana gerbangmastaskin dan prosentase jasa pinjaman sedangkan penurunan dapat terjadi karena adanya kemacetan kredit pokmas.

UPK Gandaria menerima dana gerbangmastaskin sejak tahun 2008 dan berdasarkan laporan keuangan dan data statistik tahun 2016, UPK Gandaria mengelola dana sebesar Rp248.530.000,00 sampai dengan saat ini, dengan kas di bank sebesar Rp53.500.000,00 yang merupakan simpanan atau tabungan pokmas. Pengurus menetapkan pinjaman untuk setiap anggota pokmas yaitu sampai dengan Rp5.000.000,00 dengan pengembalian 10 kali angsuran. Berdasarkan informasi yang diperoleh pada tahap awal penelitian, bentuk pertanggung jawaban yang senantiasa diberikan oleh UPK diungkapkan oleh Sektap Kota (CR) berikut:

"pertanggung jawabannya dalam bentuk pencatatan semua uang yang dikeluarkan dan pembayaran dari simpan pinjam, pengurusnya harus rajin ke masyarakat" 
Begitu pula diungkapkan oleh Pengurus UPK Gandaria (MB) berikut ini:

“Tanggung jawab kita itu kan gini, menerima dari mana berapa kemudian disalurkan berapa, menerima dari dana pemerintah jumlahnya berapa, digunakan untuk apa harus sesuai dengan proposal atau lembar kerja, peruntukannya. Kemudian secara tanggung jawab melaporkan di setiap periode tertentu. Setiap bulan menghitung membuat neraca, berapa posisi modalnya, utangnya, di banknya, keuntungannya. Pendamping minta laporannya jadi ke pendamping aja laporannya. Saya bikin seperti itu ga tau kalau yang lain. Biasanya kalau pendamping minta saya kasih jika tidak ya saya tetap bikin ada saya kumpulkan. Kalau dulu kan ada sekretariatnya mudah administrasinya kita-kita UPK ini."

Informasi yang diungkapkan oleh beberapa informan tersebut menunjukkan bahwa bentuk pertanggung jawaban dilakukan oleh UPK dalam bentuk pencatatan dan pelaporan. Administrasi pencatatan dan dokumen yang dipersiapkan pada UPK Gandaria berdasarkan penelusuran peneliti yaitu a) buku setoran dan simpanan untuk masing-masing anggota pokmas; b) daftar simpanan sukarela anggota; c) tanda terima pinjaman pokmas; d) laporan perkembangan pinjaman pokmas; e) buku kas masuk (BKM), buku kas keluar (BKL), neraca percobaan serta laporan keuangan dan data statistik.

Tanggung jawab UPK untuk memenuhi akuntabilitas sebagai pengelola dana pemerintah yang disalurkan kepada masyarakat adalah dalam bentuk laporan penggunaan dana, dan laporan perkembangan dana dalam bentuk laporan keuangan karena mengelola dana bergulir yang digunakan untuk simpan pinjam masyarakat sehingga laporan keuangan digunakan sebagai bentuk informasi arus dana bergulir UPK.

\section{Laporan Penggunaan Dana}

UPK mempersiapkan laporan penggunaan dana sebagai bentuk pertanggung jawaban UPK kepada penyalur dana sesuai dengan peruntukannya. Kewajiban UPK memberikan laporan penggunaan dana merupakan suatu keharusan bukan hanya sebagai tanggung jawab UPK terhadap pemerintah sebagai penyandang dana tetapi juga dibutuhkan oleh pemerintah sebagai bentuk akuntabilitas atas dana yang disalurkan untuk masyarakat sebagaimana diungkapkan berikut ini:

Staf Keuangan (DN) : “UPK harus mempersiapkan laporan pertanggung jawaban dana atas dana yang dicairkan dalam bentuk SPJ, bertahap sesuai dengan ketentuan yang sudah ditetapkan."

Pengurus UPK (MB) : "ya kita harus ngasih SPJ ke dinas."

Sektap Kota (CR) : "kalau laporan penggunaan dana pasti dibikin sama mereka, lalu diserahkan ke kita agar dapat diserahkan ke bagian keuangan."

Pernyataan-pernyataan tersebut baik diungkapkan oleh staf keuangan pemerintah, pengurus UPK itu sendiri maupun Sektap Kota bahwa UPK harus menyiapkan pertanggung jawaban dalam bentuk laporan penggunaan dana dan segala kelengkapan dokumennya sehingga hal tersebut menjadi kewajiban mutlak yang harus dipenuhi oleh UPK. Laporan penggunaan dana menyajikan lembar kerja UPK sesuai dengan informasi yang terdapat pada proposal awal UPK yang telah menjadi pertanggung jawaban UPK pada saat pertama kali mengajukan permohonan dana selain penyajian informasi mengenai sasaran dan rencana kegiatan UPK. UPK memberikan laporan penggunaan dana secara berkala dalam bentuk laporan realisasi 


\section{ASSETS JURNAL AKUNTANSI DAN PENDIDIKAN

tahap I dan laporan realisasi tahap II sesuai dengan ketentuan pemerintah daerah untuk memenuhi pertanggungjawabannya yang berisi informasi lebih detail mengenai penggunaan dana, lembar kerja, daftar pertanggungjawaban penerimaan dana beserta kelengkapan dokumen berupa kwitansi, nota dan lain sebagainya. Keutamaan dari informasi yang disajikan dari laporan penggunaan dana yaitu lembar kerja yang memberikan informasi mengenai alokasi penggunaan dana serta aktivitas dan tahapan kegiatan.

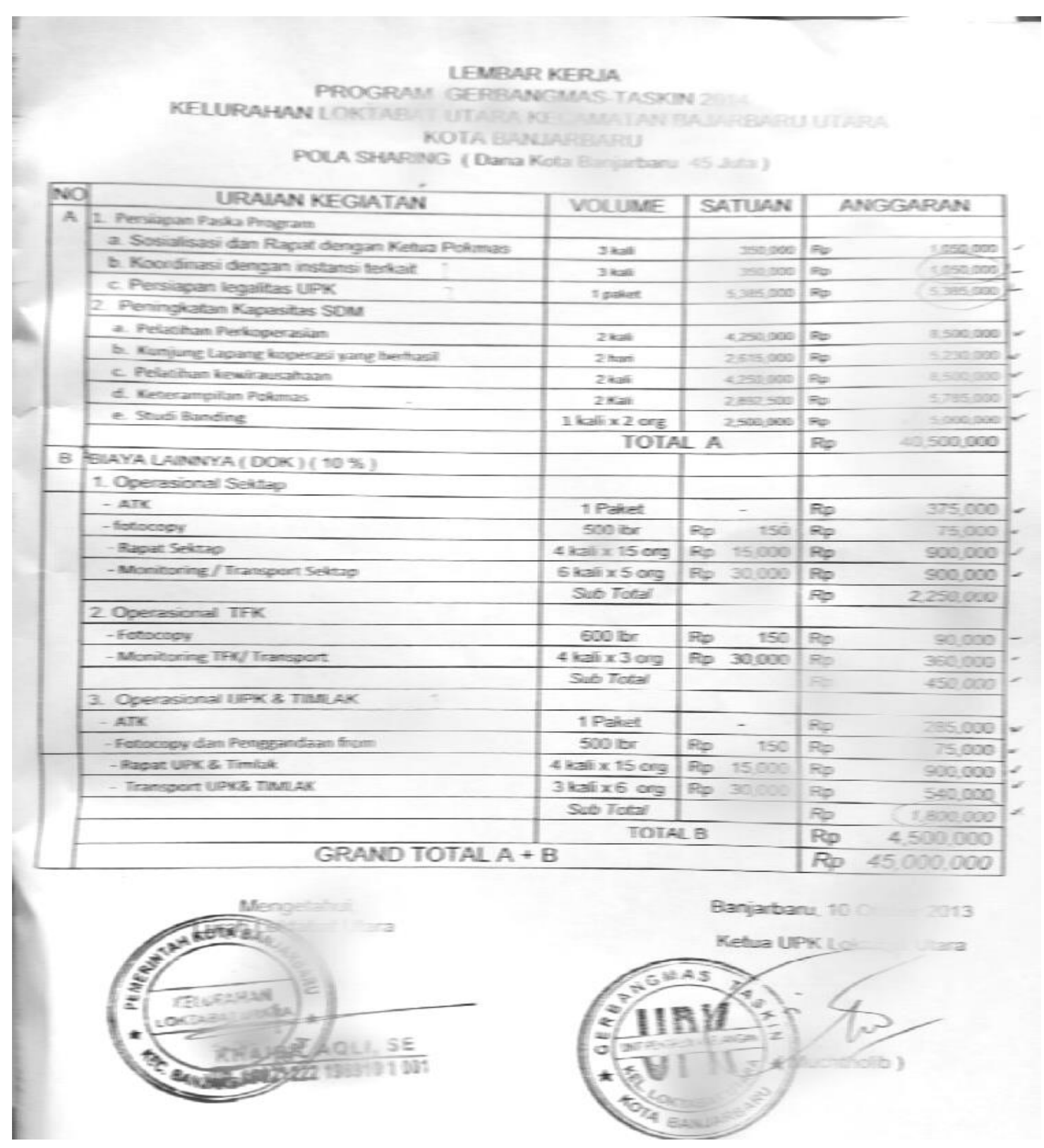

Gambar 1. Lembar Kerja UPK-G

Namun informasi penggunaan dana melalui laporan penggunaan dana sejak awal pengelolaan dana gerbangmastaskin tidak diarsipkan dengan lengkap oleh UPK selama ini karena sekretariat UPK Kota yang selalu berpindah tempat serta keterbatasan ruang arsip yang dimiliki oleh Pengurus UPK di kediamannya sendiri sebagaimana gambar 2 berikut ini: 


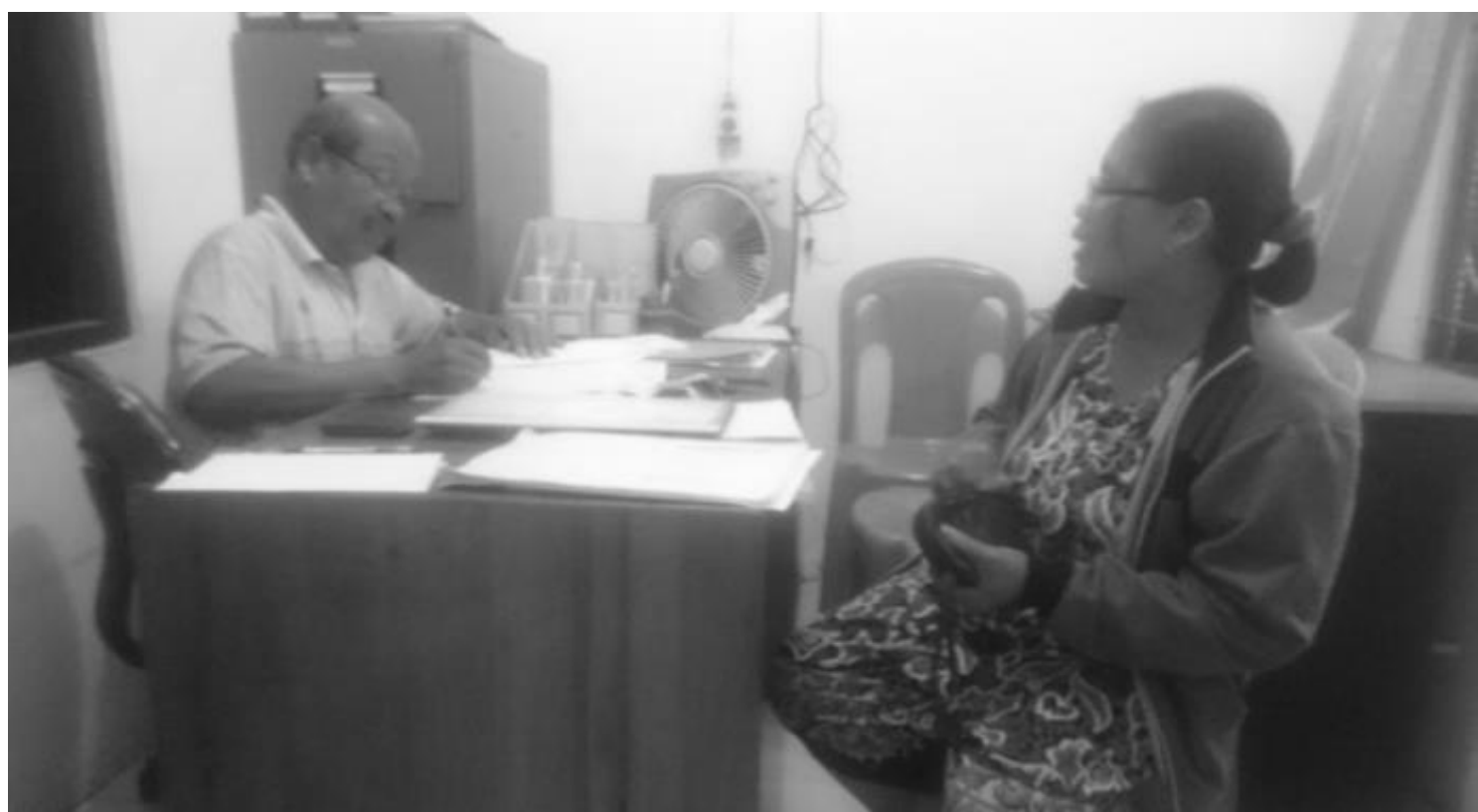

Gambar 2. Aktivitas Pengurus UPK Gandaria

Pengurus UPK memanfaatkan fasilitas seadanya yang dimiliki untuk menunjang aktivitas kegiatannya selama ini, namun begitu anggota pokmas selalu diterima setiap waktu oleh pengurus UPK yang ingin melakukan pembayaran angsuran. Tanggung jawab pengurus dalam mengelola dana dengan melakukan pencatatan serta membuat pelaporan dengan baik untuk kebutuhan informasi bagi masyarakat juga dijadikan sebagai bentuk pengawasan dan dapat dijadikan sebagai evaluasi oleh UPK.

\section{Laporan Keuangan}

Laporan keuangan sejatinya dibutuhkan untuk memberikan informasi keuangan. UPK dalam hal ini dapat menunjukkan informasi keuangan dan lalu lintas dana bergulir melalui laporan keuangan. Realitasnya menunjukkan bahwa sejak disalurkannya Dana Gerbangmastaskin pada tahun 2007, laporan keuangan hanya disiapkan sejak beberapa tahun terakhir sebagaimana diungkapkan oleh Pengurus UPK, Pendamping dan Sektap Kota berikut:

Pengurus UPK (MB) : “UPK menyiapkan laporan keuangan, ada kami buatkan, kalau disini setiap bulannya ada dibuatkan dan diserahkan ke pendamping, tapi ga selalu diserahkan, kalau diminta saja. Membuatnya pun baru beberapa tahun belakangan, tidak dari pertama, mungkin sejak tahun 2013."

Pendamping (GN) : "Ada saya bikinkan formatnya, mereka (UPK) tinggal mengikuti, supaya teratur, memang sebelumnya beberapa UPK masih beda-beda, jadi kalau disiapkan begini kan bagus."

Sektap Kota (CR) : "Nah ga tau kalau laporan keuangan mereka, yang ada hanya laporan penggunaan dana yang mereka laporkan setelah pencairan dana sebagai pertanggung jawabannya kalau perguliran dananya kurang tau detailnya."

Hal tersebut menunjukkan bahwa laporan keuangan selalu dibuat oleh UPK walaupun pada beberapa tahun belakangan dan mempersiapkan laporan keuangan bukan menjadi suatu keharusan dan hanya berdasarkan permintaan walaupun UPK 
tetap mempersiapkan laporan keuangan setiap bulannya dan mengarsipkannya sendiri. Laporan keuangan sebagai bentuk informasi arus dana bergulir tidak dilaporkan secara teratur kepada Pendamping maupun Sektap Kota. Sejatinya informasi tersebut berguna bagi UPK itu sendiri, kemudian bagi Sektap Kota sebagai pelaksana kegiatan dapat menggunakan informasi tersebut untuk diketahui pada saat ini dan digunakan sebagaimana mestinya di masa yang akan datang sebagai bentuk akuntabilitas UPK, tentunya sebagai pertimbangan untuk penyaluran dana maupun bantuan sosial lainnya terhadap masyarakat di masing-masing kelurahan.

Terpenuhinya akuntabilitas UPK yang diwujudkan melalui laporan keuangan sebagaimana telah diatur menjadi kewajiban UPK. Salah satu ukuran yang digunakan untuk mengukur transparansi dan akuntabilitas adalah laporan tahunan (annual report) (Ibrahim, 2015). Sebagaimana informasi tersebut digunakan oleh tim pendamping untuk pengumpulan data keuangan UPK walaupun tersaji secara sederhana dan apa adanya sebagaimana diungkapkan pengurus UPK (MB) berikut:

"Saya buat sederhana sesuai dengan format yang diberikan, saya bikin manual karena ga bisa komputer."

Hal senada diungkapkan oleh pendamping (GN):

"UPK Gandaria membuat laporan lengkap sampai neraca walaupun manual tetapi sesuai dengan kaidah akuntansi."

Keterbatasan pengurus UPK menyajikan laporan bukan menjadi hambatan bagi pengurus untuk memberikan informasi dengan lengkap dan jelas mengenai informasi arus dana, informasi mengenai anggota pokmas, dan juga mengenai kemacetan kredit yang selalu menjadi permasalahan utama di setiap pengelolaan dana bergulir.

Beberapa hal yang menjadi kelemahan dalam akuntabilitas pengelolaan dana bergulir dalam menyajikan laporan perkembangan dana melalui laporan keuangan maupun kelengkapan arsip dan dokumen terkait laporan penggunaan dana tidak terlepas dari ketidakefektifan pengurus lainnya pada satu UPK karena terdapat realitas yang menunjukkan adanya satu pengurus aktif yang hanya mengelola dana bergulir. Kurangnya kemampuan menggunakan komputer dan tidak jarang dibantu oleh pendamping, kemudian kurangnya alat bantu (komputer) untuk menunjang aktivitas dan kegiatan pengurus UPK, namun sejatinya sebagaimana diungkapkan oleh pendamping maupun sektap kota bahwa pengurus UPK selama ini mengelola dana bergulir dengan cukup baik.

Fasilitator kelurahan dan kecamatan dapat menjadi media yang seyogyanya dapat membantu mengatasi keterbatasan pada UPK-G. Meskipun terdapat keterbatasan dengan penyediaan sekretariat UPK, tidak menghambat antar pengurus UPK lainnya untuk dapat menjalin komunikasi, bertukar pendapat dan merundingkan suatu masalah karena pertemuan bulanan yang selalu diadakan oleh UPK bersama dengan pendamping dan juga tidak jarang dihadiri oleh sektap kota agar silaturahmi pun tetap terjaga. Melalui media pertemuan rutin bulanan itulah pendamping bersama-sama dengan sektap kota dapat memberikan pengarahan secara merata kepada seluruh pengurus UPK untuk meningkatkan akuntabilitas pengelolaan dana bergulir. 


\section{SIMPULAN}

Tanggung jawab pengurus UPK memberikan pelaporan terhadap pengelolaan dana bergulir sebagai bentuk akuntabilitas pelaporan UPK ditunjukkan dalam bentuk laporan penggunaan dana dan laporan keuangan UPK. Kelemahan dalam akuntabilitas pelaporan UPK disebabkan karena terbatasnya fasilitas dan ruang yang tersedia untuk menunjang aktivitas kegiatannya seperti sekretariat UPK, komputer sebagai alat bantu dan adanya ketidakefektifan pengurus UPK karena selama ini hanya ada satu pengurus aktif yang mengelola dana bergulir. Keterbatasan yang dihadapi peneliti adalah masalah waktu dan akses untuk mendapatkan informan pendukung. Keberadaan informan pendukung susah dijangkau oleh peneliti. Peneliti sulit menemukan data tahun sebelumnya karena pengurus belum tertib melakukan pembukuan. Sehingga dapat disarankan untuk penelitian selanjutnya dapat mencari bantuan dari pihak lain, misalnya fasilitator kecamatan atau kelurahan.

\section{DAFTAR PUSTAKA}

Anonim. (2014). Mental Miskin Sulitkan Pengentasan Kemiskinan. Diakses pada 15 Desember 2016, dari m.antarakalsel.com/berita/19239/mental-miskin-sulitkanpengentasan-kemiskinan.

Badan Pemberdayaan Masyarakat dan Pemerintahan Desa Pemerintah Provinsi Kalimantan Selatan. (2015). Program Gerbangmas-Taskin Provinsi Kalimantan Selatan Tahun 2015: Petunjuk Teknis Operasional.

Badan Pemberdayaan Masyarakat, Perempuan dan Keluarga Berencana Kota Banjarbaru. (2013). Gerbangmastaskin Kota Banjarbaru Tahun 2013.

BPS Provinsi Kalimantan Selatan. (2016). Kondisi Kemiskinan di Kalimantan Selatan Maret 2016 Jumlah Penduduk Miskin 195,70 Ribu Orang. Berita Resmi Statistik BPS Provinsi Kalimantan Selatan Nomor 039/07/63/Th.XX tahun 2016.

Hopwood, A.G. (1990). Accounting and Organisation Change. Accounting, Auditing \& Accountability Journal, 3 (1), 7-17.

Ibrahim, R. (2015). Beberapa Tantangan Akuntabilitas, Internal Governance dan "Akuntabilitas ke Bawah" untuk Pengembangan Efektivitas LSM. Jurnal Akuntabilitas Organisasi Masyarakat Sipil Edisi 3, 7-22.

Kilby, P. (2006). Accountability for Empowerment: Dilemmas Facing NonGovernmental Organizations. World Development, 34 (6), 951-963.

Komite Standar Akuntansi Pemerintahan. (2008). Akuntansi Dana Bergulir. Buletin Teknis Standar Akuntansi Pemerintahan Nomor 07.

Mantra, I.B. (2008). Filsafat Penelitian \& Metode Penelitian Sosial. Yogyakarta: Penerbit Pustaka Pelajar.

Mardiasmo. (2009). Akuntansi Sektor Publik. Yogyakarta: Penerbit Andi.

Nugroho, R. (2014). Public Policy: Teori, Manajemen, Dinamika, Analisis, Konvergensi, dan Kimia Kebijakan Edisi kelima. Jakarta: Penerbit PT Elex Media Komputindo.

Oyesanmi, O. Eboiyehi, F. dan Adereti, A. (2005). Evaluation of the Concepts, Implementation and Impact of Poverty Alleviation Programmes in Nigeria. Paper Presented at International Union for the Scientific Study of Population XXV International Population Conference Tours. France, July 2005, 18-23.

Peraturan Menteri Dalam Negeri Republik Indonesia Nomor 32 tahun 2011.

Peraturan Menteri Dalam Negeri Republik Indonesia Nomor 39 tahun 2012.

Peraturan Menteri Dalam Negeri Republik Indonesia Nomor 14 tahun 2016. 
Sucipto. (2012). Akuntabilitas Pengelolaan Keuangan Badan Keswadayaan Masyarakat (BKM) Kelurahan Penerima Bantuan PNPM-Mandiri Perkotaan Samarinda. Jurnal Eksis, 8 (2), 2326-2332.

Sugiyono. (2015). Memahami Penelitian Kualitatif. Bandung: Penerbit Alfabeta.

Wira, V. dan Gustati. (2014). Optimalisasi Dana Bergulir dalam Meningkatkan Perekonomian Masyarakat Miskin (Studi Kasus Dana PNPM Mandiri Perkotaan di Propinsi Sumatera Barat). Jurnal Akuntansi, Keuangan dan Perbankan, 1 (2), 144-150.

Yuliati. (2015). Menyibab Penyebab Keterlambatan Penyelesaian Laporan Keuangan (Studi Kasus pada Badan Keswadayaan Masyarakat (BKM) Bunul Rejo Kota Malang). Tesis Magister Akuntansi Program Pascasarjana Universitas Brawijaya Malang. 